\title{
CHANGE AND DEVELOPMENT LAW OF ADOLESCENTS' PHYSICAL HEALTH EXERCISE BEHAVIOR
}

\author{
LEIDE MUDANÇA EDESENVOLVIMENTO DO COMPORTAMENTO DE EXERCÍCIO DE SAÚDE FÍSICA DE \\ ADOLESCENTES COM BASE NOS ANTECEDENTES DA ECOLOGIA SOCIAL
}

Original Article

ARTIGO ORIGINAL Artículo Original

\author{
INVESTIGACIÓN SOBRE LA LEY DE CAMBIO Y DESARROLLO DE LA CONDUCTA DE EJERCICIO DE \\ SALUD FISICA DE LOS ADOLESCENTES BASADA EN LOS ANTECEDENTES DE LA ECOLOGÍA SOCIAL
}

\author{
Liying Yao ${ }^{1,4}$ (D) \\ (Physical Education Professional) \\ Yanwen Lü (D) \\ (Physical Education Professional) \\ Yiqiong Zhang ${ }^{3}$ (D) \\ (Physical Education Professional) \\ 1. School of Physical Education, \\ Shangrao Normal University, \\ Jiangxi, China. \\ 2. School of Health Sciences, \\ Universiti Sains Malaysia, Kubang \\ Kerian, Kelantan, Malaysia. \\ 3. Department of Physical \\ Education, Fudan University, \\ Shanghai, China. \\ 4. Universiti Sains Malaysia, 11800 \\ USM Penang, Malaysia.
}

\section{Correspondence:}

Yiqiong Zhang

Department of Physical Education, Fudan University, Shanghai, China. RyanWong305@163.com

\begin{abstract}
Background: The generation of individual behavior is closely related to the environment in which it is located and is easily affected by environmental factors. Objective: The thesis takes the social ecology model theory as the starting point, applies the five different levels of influencing factors in the theoretical model to the field of youth physical exercise behavior, and seeks the interrelationship between the various influencing factors. Methods: Using questionnaire surveys, interviews, and other research methods, the paper makes a simple theoretical combing and analysis of the healthy behavior ecology model, seeks the interrelationship between the influencing factors, propose complementary intervention strategies, and promote the development of adolescents' physical exercise habits through effective ways. Results: The motivation of sports participation, the protection of physical health, family health awareness, economic and educational environment, professional quality of physical education teachers and school exercise environment and community facilities affect the direction of the development of adolescents' physical exercise behavior. Conclusions: Only by comprehensively considering the relationship between various related factors can we better understand adolescent physical exercise development characteristics, propose complementary intervention strategies, and promote physical exercise habits effectively. Level of evidence Il; Therapeutic studies - investigation of treatment results.
\end{abstract}

Keywords: Adolescent; Exercise; Influencing factors; Physical fitness; Social environment; Students.

\section{RESUMO}

Antecedentes: A geração do comportamento individual está intimamente relacionada ao ambiente em que está inserida e é facilmente afetada por fatores ambientais. Objetivo: A tese toma como ponto de partida a teoria do modelo da ecologia social, aplica os cinco diferentes níveis de fatores influenciadores do modelo teórico ao campo do comportamento de exercício físico juvenil e busca a inter-relação entre os vários fatores influenciadores. Métodos: Utilizando questionários, entrevistas e outros métodos de pesquisa, o artigo faz uma análise teórica simples do modelo de ecologia do comportamento saudável, busca a inter-relação entre os fatores que influenciam, propõe estratégias de intervenção complementares e promove o desenvolvimento físico dos adolescentes. hábitos de exercício através de formas eficazes. Resultados: A motivação para a prática de esportes, a proteção da saúde física, a conscientização sobre a saúde da família, o ambiente econômico e educacional, a qualidade profissional dos professores de educação física e o ambiente de exercício escolar e as instalações comunitárias afetam a direção do desenvolvimento do comportamento de exercício físico dos adolescentes. Conclusões: Somente considerando de forma abrangente a relação entre vários fatores relacionados podemos entender melhor as características do desenvolvimento de exercícios físicos em adolescentes, propor estratégias de intervenção complementar e promover hábitos de exercícios físicos de forma eficaz. Nível de evidência ll; Estudos terapêuticos: investigação dos resultados do tratamento.

Descritores: Adolescente; Exercício físico; Fatores de influência; Aptidão física; Meio social; Estudantes.

\section{RESUMEN}

Antecedentes: La generación del comportamiento individual está íntimamente relacionada con el entorno en el que se ubica y es fácilmente afectado por factores ambientales. Objetivo: La tesis toma como punto de partida la teoría del modelo de ecología social, aplica los cinco niveles diferentes de factores de influencia en el modelo teórico al campo de la conducta de ejercicio físico juvenil y busca la interrelación entre los diversos factores de influencia. Métodos: Mediante cuestionarios, entrevistas y otros métodos de investigación, el trabajo realiza un simple peinado y análisis teórico del modelo de ecología del comportamiento saludable, busca la interrelación entre los factores influyentes, propone estrategias de intervención complementarias y promueve el desarrollo de la física de los adolescentes. Hábitos de ejercicio de forma eficaz. Resultados: La motivación de la participación deportiva, la protección de la salud física, la conciencia de la salud familiar, el entorno económico y educativo, la calidad profesional de los profesores de educación física y el entorno de ejercicio escolar y las instalaciones comunitarias afectan la dirección del desarrollo 
de la conducta de ejercicio físico de los adolescentes. Conclusiones: Solo considerando de manera integral la relación entre varios factores relacionados podemos comprender mejor las características del desarrollo del ejercicio físico en los adolescentes, proponer estrategias de intervención complementarias y promover los hábitos de ejercicio físico de manera efectiva. Nivel de evidencia ll; Estudios terapéuticos: investigación de los resultados del tratamiento.

Descriptores: Adolescente; Ejercicio físico; Factores de influencia; Aptitud física; Medio social; Estudiantes.

\section{INTRODUCTION}

The statistical data of the Chinese Student Physical Fitness Survey report shows that in 2015, the physical fitness measurement indicators of Chinese adolescents (7-22 years old) showed a downward trend in terms of physical fitness indicators such as endurance and strength, while the obesity and overweight of urban and rural boys and girls. The proportion has continued to increase. Some scholars sampled the physical fitness and health data of Chinese students and comprehensively evaluated the test results. The results are not optimistic: the pass rate of the comprehensive health assessment of primary and middle school students is not high and shows a downward trend with age; the passing rate of overweight and obese students is not as good as 60\%. This shows that insufficient physical exercise is an important reason for the decline in students' physical fitness.

\section{METHOD}

\section{Research object}

The thesis selected adolescent students from 13 to 17 years old (junior high school and high school) as the survey subjects, randomly selected 1100 adolescent students from 5 junior high schools and five high schools as the research sample and conducted a questionnaire survey. We distributed 1,100 questionnaires, of which 550 were boys, and 550 were girls. 1045 questionnaires were returned, with a recovery rate of $95.0 \%$. After excluding invalid questionnaires, the total number was 1015 , with an effective recovery rate of $97.1 \%$.

\section{Research methods}

\section{Questionnaire survey method}

According to the social ecology theory, human behavior is affected by multiple levels of interaction, generally including the individual level, interpersonal level, organizational level, community level, and policy level. Therefore, the design of the questionnaire on the influencing factors of adolescent physical exercise behavior is based on these five aspects, and related literature materials are searched, the theory is summarized and refined, and the "Questionnaire on the influencing factors of adolescent physical exercise behavior" is designed based on theoretical analysis and interview results. ${ }^{1}$

After the questionnaire was compiled, the initial test questionnaire was formed. After the second round of data screening, the experiment summarized the statistical data and obtained the Cronbach's coefficient a coefficient and the standardized a coefficient of each subscale of the questionnaire (Table 1).

Table 1. Reliability statistics of the subscales of influencing factors of adolescent physical exercise behavior

\begin{tabular}{c|c|c|c}
\hline Scale level & $\begin{array}{c}\text { Cronbach alpha } \\
\text { coefficient }\end{array}$ & $\begin{array}{c}\text { Normalized alpha } \\
\text { coefficient }\end{array}$ & $\begin{array}{c}\text { Number of } \\
\text { subscale items }\end{array}$ \\
\hline Individual level & 0.866 & 0.867 & 11 \\
\hline Family level & 0.91 & 0.911 & 12 \\
\hline School level & 0.899 & 0.9 & 10 \\
\hline Community level & 0.925 & 0.926 & 14 \\
\hline Policy level & 0.942 & 0.942 & 10 \\
\hline
\end{tabular}

The data in Table 1 shows that the Cronbach alpha coefficients of the family level, community level, and policy level scales exceed 0.90, and the Cronbach alpha coefficients of the individual level and school level scales are 0.866 and 0.899 . According to Henson, the internal consistency reliability coefficient index judgment principle: when $0.80 \leq a$ coefficient $<0.90$ means that the reliability of the test or scale is ideal; when the a coefficient $\geq 0.90$, it means that the reliability of the test or scale is very good. ${ }^{2}$ From this, it can be judged that the questionnaire's reliability on factors affecting adolescent physical exercise behavior has reached an ideal and very ideal level.

\section{Expert interview method}

We visited eight experts in the field of physical exercise behavior and psychology research, and communicated and exchanged with 20 front-line physical education teachers, integrated the results of interview records, determined the content of the questionnaire on factors affecting youth physical exercise behavior, and invited experts to conduct two rounds of screening to form the final questionnaire.

\section{Mathematical Statistics}

We use the sociological, statistical software SPSS22.0 to classify, analyze, and process the survey data. At the same time, perform factor analysis on the statistical data of each level, establish the correlation coefficient matrix between each level, and extract the common factors and name the data of each level through the principal component analysis method, obtain the factor loading matrix, and finally perform the analysis on each impact factor. ${ }^{3}$

\section{RESULTS}

\section{Impact analysis at the individual level}

There are a total of 11 items at the individual level. The data's statistical results are subjected to factor analysis, and the common factor is extracted by the method of feature value greater than. ${ }^{4}$ The items with a factor load greater than 0.50 are extracted, and each factor contains at least three items in principle. After analysis, we extracted two common factors and named them "sports participation motivation" and "physical health guarantee" (Table 2).

Factor 1 mainly reflects the content of motivation, interest, sports accomplishment, enjoyable sports experience, positive expectations of sports results, ${ }^{5}$ positive self-evaluation, and sports knowledge and attitudes. Some scholars believe that although obese people are more inclined to choose daily moderate-intensity activities such as walking, in public intervention activities, including walking and climbing, obese people still show lower participation than normal-weight individuals. The strength of physical exercise motivation of female college students is closely related to their physical shape, and the change of Queenlet index causes $42 \%$ of their physical exercise motivation.

\section{Family-level impact analysis}

There are a total of 12 items at the family level. ${ }^{6}$ The data's statistical results are analyzed by factor analysis with a feature value greater than 1 , and a load of each factor is greater than 0.50. After analysis, two common factors are extracted and named as "Family Cultural health awareness" and "family economy and educational environment" 


\section{School-level impact analysis}

There are a total of 10 items at the school level. The data's statistical results are subjected to factor analysis, and the common factor is extracted by the method of feature value greater than 1 . After analysis, the thesis extracted two common factors, which were named "physical education teachers'professional quality" and "school exercise environment"(Table 3).

The professional quality of physical education teachers includes three variables: the teaching philosophy, teaching methods, and professional qualities of physical education teachers; the school exercise environment includes the training awareness and behavior of school leaders, the importance of the leadership to sports, the school's financial support for sports, and education evaluation There are seven variables including the mechanism, the development of extracurricular sports activities, the equipment of venues and facilities, and the support of peers and friends. The three variables in factor 1 are all important factors affecting youth physical exercise. Modern teaching theories emphasize the importance of strengthening the leading role of teachers while giving play to students'subjectivity. Physical education is a purposeful and planned educational process for training people. Some scholars have shown that: $67.9 \%$ of students believe that physical education teachers play an important role in forming their physical exercise habits. Physical education has a greater impact on the development of students' physical exercise habits.

Table 2. Exploratory factor analysis results at the individual level.

\begin{tabular}{c|c|c}
\hline \multirow{2}{*}{ Item variables and questions } & \multicolumn{2}{|c}{$\begin{array}{c}\text { Factor load after maximum } \\
\text { orthogonal rotation }\end{array}$} \\
\cline { 2 - 3 } & F1 & F2 \\
\hline a3 sports motivation & 0.673 & \\
\hline a4 interest in sports & 0.736 & \\
\hline a5 sense of accomplishment in sports & 0.749 & \\
\hline A8 sports enjoyable experience & 0.685 & \\
\hline a9 Positive expectations of sports results & 0.667 & \\
\hline a10 positive self-evaluation & 0.643 & \\
\hline a11 Sports knowledge and attitude & 0.565 & \\
\hline a1 physical fitness & & 0.848 \\
\hline a2 health status & & 0.876 \\
\hline $\begin{array}{c}\text { a6 How much attention is } \\
\text { paid to one's health }\end{array}$ & & 0.536 \\
\hline a7 the benefits of physical exercise & & 0.553 \\
\hline Eigenvalues & 3.642 & 3.046 \\
\hline Explain the contribution rate of variation\% & 33.109 & 27.691 \\
\hline Cumulative explained variance & 33.109 & 60.8 \\
\hline contribution rate\% & &
\end{tabular}

Table 3. Exploratory factor analysis results at the school level.

\begin{tabular}{c|c|c}
\hline \multirow{2}{*}{ Item variables and questions } & \multicolumn{2}{|c}{$\begin{array}{c}\text { Factor load after maximum } \\
\text { orthogonal rotation }\end{array}$} \\
\cline { 2 - 3 } & F1 & F2 \\
\hline C1 PE teacher's teaching philosophy & 0.875 & \\
\hline c2 teaching methods of physical education teachers & 0.883 & \\
\hline C3 Professional Qualities of Physical \\
Education Teachers & 0.841 & \\
\hline C4 school leaders' training awareness and behavior & & 0.725 \\
\hline C5 School leaders' emphasis on sports & & 0.824 \\
\hline c6 school support for sports funding & & 0.779 \\
\hline C7 Educational Evaluation Mechanism & & 0.696 \\
\hline c8 the development of extracurricular & & 0.732 \\
sports activities & & 0.643 \\
\hline c9 School facilities and facilities & & 0.557 \\
\hline E10 support and participation of peers and friends & & 2.683 \\
\hline Eigenvalues & 3.804 & 26.83 \\
\hline Explain the contribution rate of variation\% & 38.04 & 64.87 \\
\hline Cumulative explained variance contribution rate\% & 38.04 &
\end{tabular}

\section{Community-level impact analysis}

At present, the sports facilities in urban communities in our country are gradually improving. The national fitness centers, fitness paths, fitness squares, and supporting sports facilities in parks provide young people with good fitness conditions and environment. Many community sports items reflect the characteristics of entertainment, fitness, and freedom, which can enable young people to participate in sports in a relaxed and comfortable environment. On the one hand, they cultivate their interest in sports and promote the development of lifelong sports habits; on the other hand, it can promote young people's socialization. Sports can improve people's physical function and behavioral ability. Understanding and observing the rules of sports events can enhance the awareness of rules in life. Especially for young people, it has more practical significance.

\section{DISCUSSION}

The thesis uses an ecological model theory to study the related factors of adolescents' physical exercise behavior. It is necessary to fully understand these factors'status and role in the ecological model to reveal the influencing factors of adolescents' participation in physical exercise and then formulate targeted intervention strategies. The influencing factors of adolescent physical exercise behavior are mainly analyzed from five levels: individual level, family level, school level, community level, and policy level. The correlation analysis of the above five levels of data through mathematical statistics shows that the correlation coefficients between the levels have reached a significant level, indicating that each level can explain its influencing factors well (Table 4).

The interaction means that different factors play a role at the same time, such as the promotion of education for young people to ensure one hour of exercise every day, and the specific measures of the national macro policy "Sunshine Sports" project Together to promote the physical health of young people. Some scholars believe that"the ecological model emphasizes the influence of the environment on individual behavior and explores the interaction of different environmental factors."This model points out the problem of multi-level factors, emphasizing that all levels of factors are crisscrossed and interact with individuals, interpersonal and small groups, organizations and institutions, communities, and policies. Therefore, family, school, and community factors can work together to affect the development direction of individual behavior changes; policy factors promote young people's physical health by formulating macrosystems and regulations.

\section{CONCLUSION}

The administrative execution of sports and the guarantee of policy resources have a macro-oriented effect on young people's physical exercise behavior and can promote and promote the sustainable development of physical exercise behavior of young people. The individual level of adolescent students is a necessary condition for them to carry out physical exercise, while family, school, community, and other factors affect individual physical exercise behavior. Policy

Table 4. Correlation coefficients among various levels of adolescent physical exercise behavior.

\begin{tabular}{c|c|c|c|c|c}
\hline Individual-level & $\begin{array}{c}\text { Family } \\
\text { level }\end{array}$ & $\begin{array}{c}\text { School- } \\
\text { level }\end{array}$ & $\begin{array}{c}\text { Community- } \\
\text { level }\end{array}$ & $\begin{array}{c}\text { Policy } \\
\text { level }\end{array}$ & \\
\hline Individual-level & 1.000 & & & & \\
\hline Family level & $0.584^{* *}$ & 1.000 & & & \\
\hline School level & $0.560^{* *}$ & $0.548^{* *}$ & 1.000 & & \\
\hline Community level & $0.469^{* *}$ & $0.595^{* *}$ & $0.506^{* *}$ & 1.000 & \\
\hline Policy level & $0.158^{* *}$ & $0.194^{* *}$ & $0.320^{* *}$ & $0.378^{* *}$ & 1.000 \\
\hline
\end{tabular}

Note: ** means a significant correlation at the 0.01 level (bilateral). 
factors are a powerful driving force for the physical exercise behavior of adolescent students. Only by comprehensively considering the relationship between various related factors can we better understand adolescent physical exercise development characteristics, propose complementary intervention strategies, and promote physical exercise habits through effective ways.

\section{ACKNOWLEDGMENTS}

The work was supported by the National Social Science Foundation of China (Grant: 19BTY092).

All authors declare no potential conflict of interest related to this article

AUTHORS' CONTRIBUTIONS: Each author made significant individual contributions to this manuscript. Liying Yao and Yiqiong Zhang participated in the design of this study.,and collected important background information. Yanwen Lu performed the statistical analysis. Liying Yao drafted the manuscript. All authors read and approved the final manuscript.

\section{REFERENCES}

1. Hunt SE. Prospects for Kurdish ecology initiatives in Syria and Turkey: Democratic confederalism and social ecology. Capitalism Nature Socialism. 2019 [cited 202121 Jun];30(3):7-26. Available from: https://uwe-repository.worktribe.com/output/902240/prospects-for-kurdish-ecology-initiatives-in-syria-and-turkey-democratic-confederalism-and-social-ecology

2. Stevens $M$, Rees $T$, Polman R. Social identification, exercise participation, and positive exercise experiences: Evidence from parkrun. J Sports Sci. 2019;37(2):221-8.

3. Kim MS, Cardinal BJ. Differences in university students' motivation between a required and an elective physical activity education policy. J Am Coll Health. 2019;67(3):207-14.
4. Ince ML. Supporting learning of practitioners and early career scholars in physical education and sports pedagogy. Sport, Education and Society. 2019;24(6): 584-96

5. Lawson HA. The physical education system as a consequential social determinant. Quest. 2020 [cited 202121 Jun];72(1):72-84. Available from: https://www.tandfonline.com/doi/abs/10.1080/ 00336297.2019.1627224

6. Richardson EV, Blaylock S, Barstow E, Fifolt M, Motl R. W. Evaluation of a conceptual model to guide health care providers in promoting exercise among persons with multiple sclerosis. Adapt Phys Activity Quarterly. 2019;36(1):109-31. 